\title{
Challenges to the Conservation of Subak System as World Cultural Heritage in Bali
}

\author{
I Nyoman Norken, I Ketut Suputra and I Gusti Ngurah Kerta Arsana \\ Department of Civil Engineering, Faculty of Engineering, University of Udayana, Jimbaran, Badung 80361, Bali, Indonesia
}

\begin{abstract}
Subak in Bali is believed to have been existing from earlier than the ninth century. Throughout this long period, Subak has been successfully utilized water resources for irrigation. Subak has been recognized as world cultural heritage by UNESCO since 2012. Currently, however, the sustainability of the system and its existence in the future is a big concern. This research is a literature review that aims to identify the challenges and provide option of solutions to sustain the Subak. The study showed that some operational and maintenance aspects of Subak are alarming, such as some network deterioration, limited availability of maintenance facilities either from government or farmers. Despite this condition, religious tradition of Subak is still carried out, although the processions vary from one Subak to another. There are several challenges in regards to Subak conservation: (1) reduction of the Subak area, resulting in declining income to support a decent life; (2) deterioration of quality and quantity of water resources; (3) the age of farmers is above 40 years with a heavy financial burden; (4) there are no clear external regulations to support Subak conservations. This study suggests several strategic steps in keeping the sustainability of Subak. The strategic steps include: refunctioning government officials; providing government support to reduce cost levied to farmers; facilitating collaborations between farmers and other stakeholders; promoting alternative commodities which have a higher financial value; preventing and repairing damages of upstream areas; controlling pollution; forming a coordination board at a provincial, regency and river basin level; building the Subak information systems; providing supervising mechanism, and encouraging academics and students to participate in an effort to preserve Subak itself.
\end{abstract}

Key words: Subak in Bali, world cultural heritage, conservation, challenges, strategic steps.

\section{Introduction}

Subak is an irrigation system in Bali, which has existed for a long time, spanning over several generations (Fig. 1). Subak is a traditional irrigation system, whose configuration is based on the socio-religious philosophy of Tri Hita Karana, and rooted in the traditions of Hinduism in Bali. Tri Hita Karana conveys meaning to maintain a coherent and harmonious relationship between humans and god (Parahyangan), humans and other humans (Pawongan) as well as humans and nature and their environment (Palemahan). Subak is predicted to have existed before the ninth century. Until today, the Subak system is still utilized to sustain the tradition of water usage and management as well as various activities related to irrigation [1].

Corresponding author: I Nyoman Norken, Ph.D., research field: water resources management.
As a legacy and a tradition that has existed for hundreds of years, Subak has been recognized as a UNESCO world cultural heritage site on June 29, 2012 [2]. Furthermore, the World Heritage Committee outlined Subak as a world heritage property cultural landscape of Bali province: the Subak system as a manifestation of the Tri Hita Karana philosophy [3].

Although Subak receives national and international recognition for its irrigation system management, some Subak observers and researchers are deeply concerned with the sustainability and existence of Subak today. Steve Lansing, a researcher on Subak since 1974, states that there is an extensive reduction of rice field areas from year to year due to land conversion, as shown in Fig. 2 [4]. High rate of land sales by local farm owners, pushed by exposure to commercialism and capitalism, is one of the triggers of this conversion [5]. 


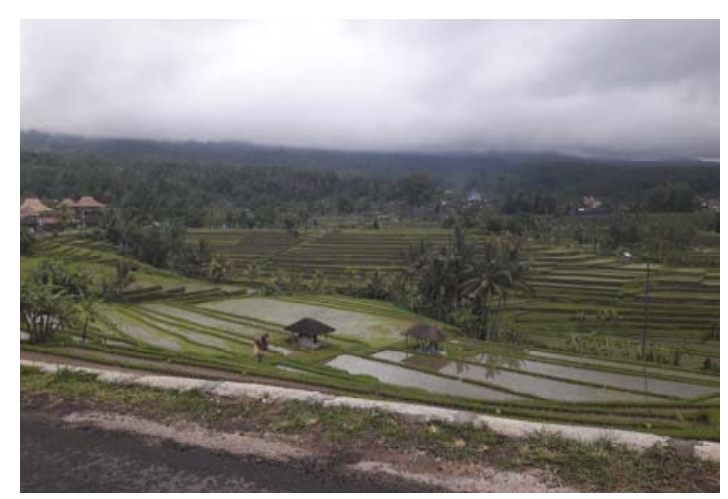

Fig. 1 Subak—an irrigation system.

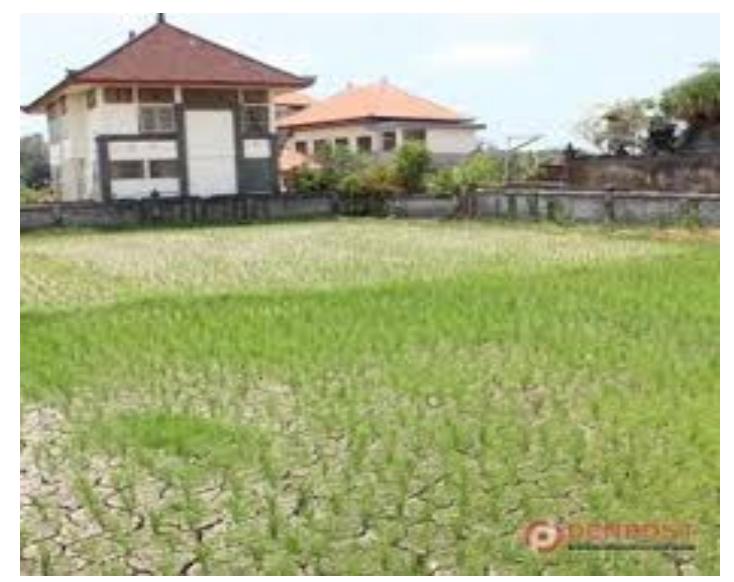

Fig. 2 Rapid conversion of Subak area.

Consequently, this condition will put pressure on the existence of the Subak system. As a result of a continuous depreciation of rice field areas and various problems faced by Subak nowadays, scientists are concerned with issues of Subak and farming systems. As a farming system is one of the bases of the Balinese culture, the erosion of Subak may contribute to the erosion of the Balinese culture as a whole. A series of erosion mitigation efforts need to be carried out to prevent Subak areas from conversion over time. With such rapid changes occurring in the Subak system in recent decades, this paper attempts to examine the challenges and propose steps that need to be carried out now and in the future in order for Subak, as a world cultural heritage site, to be sustained and maintained wherever possible.

\section{Subak and Its Development}

Although Subak system in Bali has existed for more than 1,000 years, the formal regulation of Subak was only promulgated in 1972 . The provincial regulation (Perda) No. 02 /PD/DPRD/1972 concerning irrigation formally defines Subak as a religious socio-agrarian organization, which was historically established to manage water utilization and other irrigation-related issues in a region [6]. Many researchers [7-9] have also provided a definition of Subak with various viewpoints, such as Subak is rice field areas that obtain water from a single source; Subak is an organization of wetland farmers that obtains irrigation water from a common source; Subak is a number of rice fields that receive water from the same channel or from the same branch of a canal and become one irrigation area. In relation to the Subak system, there is a temple or Pura called Pura Bedugul dedicated to worship Dewi Sri, the manifestation of god as the goddess of fertility [7]. In summary from the above description, Subak is a traditional socio-religious community organization autonomously formed to regulate water from its source to irrigate rice fields. However, later on, Subak organization was also formed to regulate agricultural farming in general not only limited to rice fields but also dry land farming known as the "Subak Abian" [8, 10]. In connection with the history of Subak, it is very difficult to trace the beginning of the existence of Subak in Bali, but it is belived to have existed since the first time that rice filds were introduced in the ninth century, according to the Sukawana AI inscription, 882 AD [9, 10]. In addition, the inscription of Klungkung also mentioned the word "kasuwakan" in Balinese language that changed into "kasubakan", which means Subak area or an irrigation area [10].

Relating to the management and development of Subak, it is described that after Bali under the reign of the Majapahit Kingdom in 1343 AD, an Asedahan also called Pasedahan was appointed with the duty of organizing some Subaks. Asedahan, later changed into Sedahan, had the duty to collect suwinih or taxes levied on agriculture and to coordinate water 
distribution on Subaks. During the Dutch colonization era, the position of a Sedahan was strengthened by the appoinment of another Sedahan at the district level and Sedahan Agung (the topmost position of a Sedahan) at the regency level. After the era of independence, Sedahan and Sedahan Agung were established as supervisors of Subak from government element through a provincial regulation, but since the reformation era in 2000, the position of Sedahan and Sedahan Agung has received less and less attention $[10,11]$.

During its development, the number of Subak is also constantly changing. It was noted that in 1971 there were 1,193 Subaks, 1,331 Subaks with an area of 102,178 hectares in 1991 [10], 1,546 Subaks in 2009 and 1,599 Subaks in 2013 [12]. Ironically, since the period 1997-2008, there has been a conversion of irrigation areas of 6,361 hectares, or an average of 579 hectares per year. The irrigation areas in Bali currently remain 82,095 hectares. In the last decade, the decline of Subak areas due to land conversion to non-agricultural fields was estimated to be about 1,000 hectares per year [4].

\section{Subak Current Condition}

As an irrigation system, although Subak is a traditional system that has existed for generations, it still operates. However, issues related to Subak's current conditions can generally be described as follows.

\subsection{Network and Irrigation Structures}

Although Subak is a traditional irrigation system, but its network and structure system is not much different from the irrigation system that exists today. According to Suputra [13], the network and the hydraulics structures existing in Subak system include: empelan (weir), bungas (water-intake), telabah (canal), tembuku (distribution structure/box) and complementary structures.

Empelan is a structure to raise river water level and bungas is a water intake structure located at the empelan to divert water to canals. Telabah connsists of telabah gede (primary canal), telabah pemaron (secondary canal), telabah cerik (tertiary canal), talikunda (quarterly canal) and pengutangan (drainage canal). Telabah can also be in the form of aungan (tunnel), where canal breaks through the hills. Tembuku (distribution structure/box) consists of tembuku aya (primary distribution structure/box), tembuku pemaron (secondary distribution structure/box) and tembuku cerik (tertiary distribution structure/box). Complementary structures consist of abangan (water bridge), pekiuh (side canal spillway), petaku (waterfalls structure), jengkuwung (culvert), keluwung (small culvert), titi (bridge) and telepus (siphon).

Subak, as mentioned above, is also completed with Pura/temple (place of worship), which is called Pura Bedugul (Subak temple) that generally exists at each Subak area. Pura Ulun Empelan is also located near the weir (empelan) as well as several other temples associated with the Subak [7, 14]. In the past, irrigation structures were made from very simple materials, such as heaps of stone for weir, pieces of coconut palms or banana trees for distribution structures, while the irrigation canal was made in the form of natural or excavated soil. Repair and maintenance of networks and irrigation structures were carried out by all farmers (members of Subak), which was conducted continuously before the intervention of the government [14].

\subsubsection{Network and Irrigation Structures Condition}

Although lately there has been assistance from the government with many improvements, some network has been damaged. For example, a number of damaged and unutilized canals and structures in the irrigation area of Mambal in Badung regency demand a serious attention of the local government to provide fund for the operation and maintenance [15]. In addition, Norken et al. [1] point out that the damaged irrigation networks is partly in the form of excavated 
soil and partly structures that were made from masonry. For example, in the regency of Bangli in 2015, the damaged irrigation canals that were within the responsibility of the government reached some 38 $\mathrm{km}$, while in Buleleng, the damage reached $199 \mathrm{~km}$ and 721 irrigation structures were deteriorated (Fig. 3). Besides, many tertiary canals managed by the farmers are also damaged. This has occurred almost in all areas of Bali. Most of the network is still in poor condition due to the limited ability of the local government and farming communities to conduct maintenance [16].

3.1.2 Maintenance of Network and Irrigation Structures

Maintenance of network and irrigation structures is carried out by the government and farmers' participations. During the enactment of the Indonesian government regulation No. 20 of 2006, which is a derivative of national law No.7 of 2004 regarding water resources (lifted in February 2015) [6], the rights and responsibilities of the central and local government are described as follows: irrigation area with an area of over 3,000 hectares becomes the authorities and responsibilities of the central government, irrigation area ranging from 1,000 hectares to 3,000 hectares becomes the authorities of the provincial government, and an area that is smaller than 1,000 hectares is a full authority and responsibility of regency/city government. In addition,

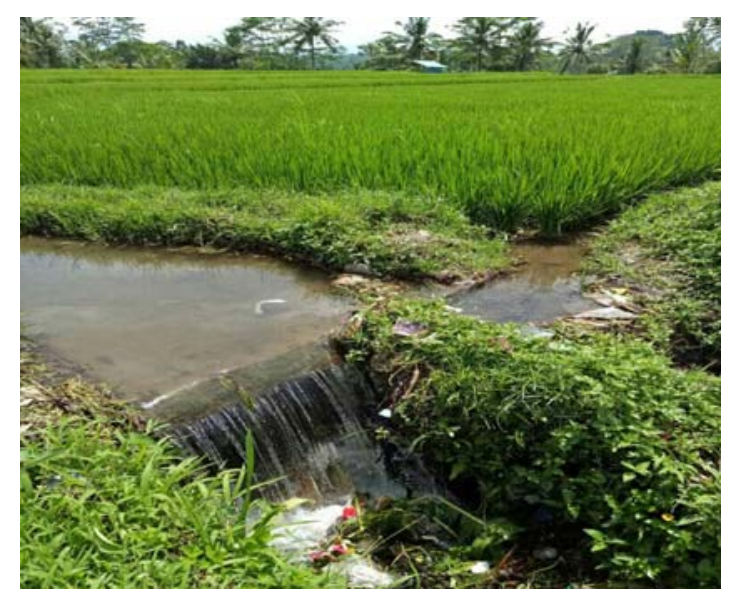

Fig. 3 Damaged irrigation canal. the primary and secondary networks are the responsibility of the government, while the tertiary network is the sole responsibility of the farmers [17]. Based on the division of the authority in the operation and maintenance of the irrigation networks, the responsibility of the regency/city government is quite heavy, due to handling extensive Subak irrigation areas, while the ability of the regency/city government to provide maintenance costs is very limited.

Although the government has taken the responsibility in accordance with the assigned duties, most networks and irrigation structures are not yet fully capable of being properly maintained. Until now, most canals which are in bad condition are at the tertiary level, where the members of Subak perform maintenance of irrigation networks with limited resources. The maintenance includes several activities, for example, mutual cooperation (called gotong royong), raising funds and other businesses, such as a formation of cooperatives and levies to ducks breeders in order to perform maintenance activities $[1,18]$.

\subsection{Organization}

Generally, each Subak in Bali has a name and organization. Although the organization structure is sometimes very simple, but it is quite effective in regulating the activities undertaken by farmers. The organization structure consists of members of Subak (Kerama Subak) and administrators (Prajuru Subak). Pitana [7] describes that a small Subak is only led by a chairman called Kelihan Subak or Pekaseh, and a larger Subak consists of Prajuru (administrators), whose position is divided into Pekaseh (chairman), Petajuh (deputy chairman), Penyarikan or Juru Tulis (secretary), Kasinoman or Juru Arah (information division) and Saya (a special assistant related to religious activities). A very large Subak containing several Subaks is called Subak Gede (big Subak) and chaired by the Pekaseh Gede (big Pekaseh), and vice big Pekaseh. The year 1980 was the beginning of the formation of Subak organization that covers the river 
catchment area, which is called Subak Agung (grand Subak) led by Pekaseh Agung (grand Pekaseh). Subak can also be sub-divided into smaller portions called tempek led by a Kelihan Tempek, and a Kelihan Tempek is under Pekaseh [9].

In the past, Subak supervising and mentoring were undertaken by the so-called Sedahan at district level, which was also a tax collector clerk, while the regency level conducted by Sedahan Agung (grand Sedahan) as the supreme mentor. The supervisor of Subak was usually directly headed by the head of the regency revenue office. One of the most prominent roles of the Sedahan and Sedahan Agung was to regulate water distribution among Subaks or water intakes or weirs and conducting coordination with other government agencies. Generally, the members of Subak strongly adhered to the decision of Sedahan and Sedahan Agung in managing water. Sedahan and Sedahan Agung were very respected by the members of Subak. Up to a certain point, Subak organizations still function well. However, since the introduction of regional autonomy government at the regency level in the 2000s, Sedahan and Sedahan Agung as the mentor of Subak from government officials have unclear functions and existence. This condition causes confusion among members of a Subak that needs guidance and consultation relating to various problems faced by subak itself [11].

This situation was confounded by the fact that Bali province regulation No. 9 of 2012 on Subak [19], which suggested a new institution called Majelis Subak (Subak assembly), whose duty is very different from Sedahan and Sedahan Agung. Until today, the actual Subak assembly has not yet been established. Currently, the mentor of Subak is undertaken by the Department of Culture at regency level. In this situation, again, it is very difficult for Subak handling problems related to water resource management as well as issues related to agriculture in general. This is simply because the officials of this department do not have any understanding about Subak system. In addition, currently there is a strong decline of the young people's interest to work in the agricultural sector, especially in Subak wetlands, impacting the age of the farmer members of Subak who are generally aged above 40 years, even the majority of them are over 50 years. Consequently, the members of Subak workforce are certainly working with less energy and productivity, which ultimately impacts the overall decline of Subak productivity [13].

\subsection{Regulation}

The regulation of Subak organisation is called awig-awig. Awig-awig are regulations that govern the activities, organizations, and rights and obligations of the members of the Subak. Awig-awig can be expanded and supplemented with additional rules, called perarem or pasuara. Perarem or pasuara is usually created to adapt to changes that may occur to meet the demands of the farmers as well as members of Subak. Awig-awig is usually written in Balinese language and endorsed by the government as Subak mentor at the regency level. However, not all awig-awigs of Subak are made in writing. Nevertheless, Subak regulations or the awig-awigs are always respected and followed by its members. In addition to awig-awig which governs Subak internally, Bali provincial government also issued a regulation relating to irrigation system in the form of provincial regulation (Perda), such as Bali provincial regulation No. 02/PD/DPRD/1972 on Bali provincial irrigation, which is then amended by provincial regulation of Bali No. 9, 2012 regarding Subak [6, 19]. The most important thing in the regulation No. 02/PD/DPRD/1972 is the reinforcement of duties and functions of government officials or Subak mentors [6]. Another regulation related to Subak is the provincial regulation No. 9 of 2012. The regulation suggested a Subak assembly whose members consist of Pekasehs; the assembly's duties are immensely different from Sedahan and Sedahan Agung [19]. The position of Sedahan and Sedahan Agung (grand 
Sedahan) is no longer appointed as government officials to supervise and mentor Subak. Historically, Sedahan and Sedahan Agung already had a long track record in protecting the existence and sustainability of Subak in Bali [11, 20].

At the national level, Subak is recognized by the central government regulation No. 20 of 2006 on irrigation, which is now not valid and does not have its amendment, because the law No. 7, 2004 on water resources along with its derivatives has been lifted since February 18, 2015 by the Constitutional Court of the Republic of Indonesia [21]. The government regulation No. 20 of 2006 regulates a board named Irrigation Commission, which functions as a coordinating body supervising water user farmers, and more or less has the same function as Sedahan and Sedahan Agung in Subak. While at the international level, UNESCO recognizes Subak as a world cultural heritage site on June 29, 2012, and has been followed up by the publication of the decree of the governor of Bali No. 11/03-H/HK/2014 on coordination forum of management of world heritage landscape and cultural of Bali province [2]. Thus, Subak does not only belong to the people of Bali, but also to the people of the world. It is believed that the key factor of maintaining the sustainability of the Subak system is the Sedahan and Sedahan Agung themselves. However, the new regulations do not even support the (re-)appointment of the Sedahan and Sedahan Agung. These conditions eventually become counterproductive and naturally weaken the efforts to preserve Subak.

\subsection{Water Management and Distribution}

The source of water for Subak is generally from rivers or springs, and diverted through a free intake to canal (telabah) or tunnel (aungan). As the traditional irrigation systems were built long time before the (modern) irrigation system is technically known, water has been divided and distributed using traditional ways. For the distribution of water in the distributing structure (tembuku), Subak system uses a ratio of area of the rice fields and a measurement that is called ayahan, which is a measurement standard based on the amount of seeds used. In addition, ayahan unit means one unit of labor (people) to be incurred when farmers Subak members conduct activities, such as repairing canals, distribution structures or other activities. Ayahan unit is equivalent to the size of the seed used and approximately the same as the area of rice fields that needs rice seeds. Ayahan unit is estimated equal to the rice field that requires about $25 \mathrm{~kg}$ of seeds or equivalent to about 0.3-0.5 hectares of rice fileld. One ayahan is entitled to water at the amount of one tektek or one kecoran. One unit tektek or kecoran is water that flows continuously through a simple spillway structure which has a width of approximately 8-10 cm, with a depth of approximately $1 \mathrm{~cm}$. One tektek is not always the same as other Subak [22]. The basic principle of water distribution system in Subak is the emphasis of fairness in obtaining water. Therefore, tektek unit is still supplemented by the agreement of the Subak members through deliberation. The consideration which is supposed to be made during deliberation involves the distance of the rice fields being watered from a water source and the porosity of soil [11].

If the water flow is not enough to irrigate the whole area of rice fields included in one Subak, the water distribution is carried out using a rotation. In the rotation system, Subak is divided into a smaller portion called tempek (e.g., one Subak is divisible into two or three tempeks). Subsequently, rotation of water distribution is directed to each tempek. The rotation pattern is usually supervised by a patelik or a pangliman (an officer appointed to observe the rotation of the water). Besides water rotation, the other water management system in Subak is known as nyorog (adjusting planting time) or nugel bungbung system (water scheduling). Subak with a large area or some Subak with a water source from a weir (empelan) is divided into three blocks/parts (upstream, 
midstream and downstream). Subak which is located in the upstream obtains water first (called ngulu). Subak located in the middle obtains water after the upstream rice field finishes the preparations of land (called maongin). The downstream Subak obtains water after midstream finishes preparations of land (called ngasep). Differences in the provision of water for each area range from two to four weeks. In terms of setting the cropping pattern, generally it is very dependent on the availability of water and the season. During the rainy season, rice is planted simultaneously (called kerta masa), whereas during the dry season, when the supply of water decreases (called gadon), it is done by adjusting the planting schedule or rotations. Subak organizations schedule the cropping patterns in detail, through time limit for starting to sow the seeds (ngurit) and starting to plant the rice (nandur) up to the deadline. Furthermore, the type of rice that may be planted is also scheduled, such as rice with a long lifespan/Balinese rice (called tebak/tebek taun) or rice with a short lifespan (tebak/tebek cicih) [20, 22]. Setting the cropping pattern is manifested in the regulation (awig-awig) or by agreement (perarem) over the Subak member meeting (paruman). This meeting is carried out before rice planting is undertaken. If it is violated, then the farmers concerned will be subject to sanctions, such as fines in accordance with the stipulation in awig-awig or in perarem [20]. In terms of organising water in Subak, water management is made by the leaders of Subak in the region or between regions through an agreement. In the event of a disagreement between the leaders or among different Subaks, the Sedahan and Sedahan Agung as a Subak supervisor plays a very important role in coordinating and distributing the use of water between the Subaks. Although the water management in Subak system has been carried out as fairly as possible, the problem Subak faces today is the decline of water availability during the dry season. It is suspected as a result of deterioration condition of the upstream region (forest) because of a very severe destruction. This situation further results in a frequent crop failure. Besides water scarcity, a crop failure might also be caused by various types of rice crop pests, such as rats, leafhoppers, etc.. Thus, it boils down to an income reduction of farmers which is already very little due to the ownership of paddy field that is no more than 0.5 hectares on average per farmer $[18,20]$. In anticipating this situation, there is an initiative from the government to help farmers in some areas to provide water pumps in an effort to use ground water as a source of irrigation water for Subak, but since the cost of its operation and maintenance is imposed on the farmers, it is considered very burdensome.

\subsection{Religious Tradition}

The series of religious rituals in Subak can not be separated from the implementation of the Parahyangan element of Tri Hita Karana. The purpose of the religious ceremonies is based on the Hindu religion in Bali, wishing Lord Vishnu (the manifestation of god, almighty as the preserver of life) and Dewi Sri (the manifestation of god, almighty as the goddess of fertility) to bless prosperity and and abundant agricultural yields [7]. All members of Subak conduct several joint ceremonies, which start from the ceremony of signaling diverting water from the water source to the irrigation canal called Mapag Toya or Mendak Toya, and end with the ceremony called Pakelem ceremony, which is performed every year together with the entire Subak chairmen within a regency. Mapag toya or mendak toya ceremony is performed at Ulun Empelan Temple, which is located near the weir or the water source, while other ceremonies are performed at Subak's temple (Pura Bedugul), which is located within the Subak area. Meanwhile, Pakelem ceremony is conducted at the Ulun Danu Temple, which is located at the Lake Tamblingan in Tabanan regency or in other similar temple in Bali [1, 7, 23].

Besides the joint ceremonies, there are also ceremonies 


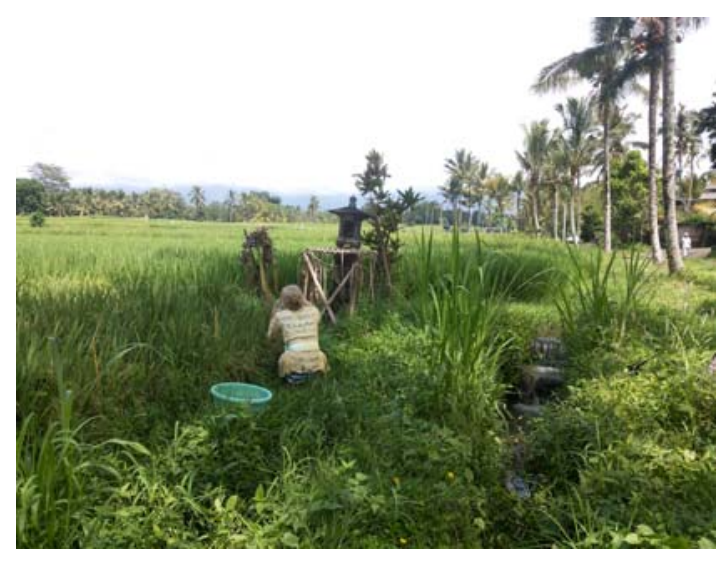

Fig. 4 A ritual by a land owner.

conducted by the individual members of the Subak, starting from a ceremony of channeling water from a canal to a rice field called ngendagin to a mantenin ceremony in which an offering is given to the rice stored in a barn located at home of rice fields owner called lumbung. A ritual by a land owner is performed at the temple of ulun carik or sanggah catu or sanggah pengalapan, which is located at the upstream of the fields and at the entrance of a water intake (Fig. 4). The series of religious rituals until now are still being carried out by Subak members, although the procession, type and magnitude of the rituals slightly vary between one Subak and the other $[1,7,23]$.

\section{Challenges of Subak Preservation}

Based on the above condition, the challenges in the preservation of Subak at the present time and in the future can be presented as follows.

Firstly, the reduction of Subak areas that may occur due to land conversions reaches up to about 1,000 hectares every year, and possibly higher than that because of the development or expansion of residential, commercial and tourism areas. On the other hand, farmers' land ownership is dwindling; consequently, it is very difficult for farmers to be able to achieve a decent life when they rely their livelihood solely on wet land farming. Secondly, the condition of irrigation networks and structures on Subak is mostly in poor condition due to lack of funding in its operation and maintenance and a decline in the quantity and quality of water resources availability due to forest destruction and pollution, causing crop failures and conflicts over water with other sectors. Thirdly, financial burden borne by farmers is very heavy, which includes land tax, cost of land preparation, fertilizers, repair of irrigation networks, religious activities and others, while income from farming is relatively low and the age of farmers is generally more than 40 years. This causes farmers to be very difficult to innovate and improve productivity. Finally, there is a lack of coordination and supervision from the government, since the non-existence of the position of Sedahan and Sedahan Agung as official mentors and the lack of regulation support at the national level after the cancellation of law No. 7 of 2004 on water resources along with its implementing regulations, including regulation No. 20 of 2006 on irrigation [21].

\section{Strategic Steps for Subak Preservation}

The challenge and issues faced by Subak system as a whole will be severer and more difficult, especially in years to come, then strategic measures must be taken both by the government and other stakeholders in order for Subak to be admired throughout the world. As described by Norken et al. [16, 24] and suggestions from several groups of discussions and seminars related to Subak in Bali, steps that need to be undertaken include the following:

(1) Firstly, the government should provide more incentives in the form of agricultural insurances in the event that farmers undergo a harvest failure. In addition, a continual support is required in an effort to ease the financial burden in the form of subsidies for production facilities, repairing and maintaining irrigation networks, as well as assistance to increase crop yields. Facilitate farmers to plant commodity alternatives beyond rice, which have a higher economic value during the dry season, such as watermelons, soybeans, etc.. Strengthen the presence 
of Subak cooperatives business, as well as facilitate the partnerships between Subak and various parties, such as tourism, businesses, etc., to mutually collaborate in an effort to increase the welfare of farmers.

(2) Secondly, the government should revive the position of Sedahan and Sedahan Agung as Subak's mentor from the government through regional regulation (regency and provincial levels), and proclaim regulations and legislation to support at national level. It needs to review the existing regulations at regional level, because they are incompatible with the intention and spirit of Subak preservation (it has to be noted that Sedahan and Sedahan Agung used to possess a very long historical value and to be respected by the Subak members in dealing with irrigation management including conflict resolutions). At the national level, it is necessary to regulate the traditional irrigation system more comprehensively so that Subak becomes a local wisdom (with its acknowledgement and recognition as a world cultural heritage).

(3) Thirdly, the government should undertake coordination with Subak stakeholders more intensively in an effort to prevent and repair damages of the upstream regions (forest and cultivated areas), and control the pollution of water resources by involving a wide range of stakeholders and communities to improve the water system (surface-water and ground-water) as a source of water for irrigation and for other purposes, and also should establish a coordinating body of water resources management at the provincial, regencies, as well as at the watershed level.

(4) Fourthly, the government shoud provide mechanism of coaching for Subak and other traditional institutions continuously in an effort to preserve as local wisdom for a competitive advantage of Balinese community, and provide data of Subak activities by building Subak information systems in Bali.
(5) Finally, universities in Bali should encourage academics and students to make Subak a place to perform activities in implementing the three higher education services (education, research and community services), therefore Subak as a traditional irrigation system is capable of competing in the era of globalization.

\section{Conclusions}

The sustainability of Subak is currently quite critical in most aspects, these include the fact that a number of irrigation networks and structures are in poor condition and there is a limited fund available at both the government and farmers to maintain irrigation networks. At present, Subak organizations is still running, but since 2000, the position of Sedahan and Sedahan Agung as government officials as Subak mentors did not exist any longer.

Challenges of Subak preservation at present and in future include a reduction of Subak area due to land conversion, farmers with a small income without achieving a decent life, a decrease of quantity and quality of water resources and pollution, the ages of Subak members farmers over 40 years, the financial burden borne by farmers to operate the Subak system, unclear and less regulation support from both the regional and national levels.

Strategic steps suggested to ensure the sustainability of Subak are Sedahan and Sedahan Agung as mentors and supervisors of Subak need to be revived. The government support is still needed to lighten the load of farmers' financial burden, build the partnership between Subak and other stakeholders, explore alternative commodities except rice, prevent damages in the upstream areas as well as pollution control, establish a coordinating board for water resources management, form Subak information systems, provid guidance mechanism for Subak development and encourage to academics and students to make Subak a place to implement the higher education services. 


\section{References}

[1] Norken, I. N., Suputra, I. K., and Arsana, I. G. N. K. 2015. "Aspects of Traditional Religious Activities on Subak Irrigation: Case Study on Subak Piling, Penebel District, Tabanan Regency.” Civil Engineering Program, University of Udayana, Denpasar. (in Indonesian)

[2] Pastika, M. M. 2014. "Decision of the Governor of Bali No. 11/03-H/HK/2014.” Coordination Forum of World Cultural Heritage Management, Cultural Landscape of Bali Province, Governor of Bali, Denpasar. Accessed January 3, 2014. http://whc.unesco.org/document/134917. (in Indonesian)

[3] Ukirsari, M. 2012. "UNESCO Plaque, Ecognition Subak as a World Heritage 2012.” Accesed September 25, 2012. http://nationalgeographic.co.id/berita/2012/09/plakat-une sco-pengakuan-subak-sebagai-warisan-dunia-2012. (in Indonesian)

[4] Finlayson, R., and Paramita, E. 2013. "Subak, Bali Irrigation System, Being on the Verge of Destruction.” Accesed August 30, 2013. http://www.worldagroforestry.org/news/subak-sistem-irig asi-khas-bali-berada-di-ambang-kehancuran.

(in Indonesian)

[5] Sutika, I. K. 2014. "Concerns of Disappearance of Subak System in Bali.” Antara Bali. Accesed March 9, 2014. http://www.antarabali.com/berita/49575/kekhawatiran-le nyapnya-sistem-subak-di-bali. (in Indonesian)

[6] Subhakti, S. 1972. "Regional Regulation (Perda) of Bali No. 02/PD/DPRD/1972 of the Bali Provincial Irrigation.” Provincial Legislature of Bali. Accessed February 23, 1972. http://jdih.baliprov.go.id/uploads/produk /1972/PERDA_2-PD--DPRD-1972-_1972.pdf. （in Indonesian)

[7] Pitana, I. G. 1993. "Subak, Traditional Irrigation System in Bali: A General Description.” In Subak, Traditional Irrigation System in Bali, edited by Pitana, I. G. Denpasar: Upada Sastra Publisher. (in Indonesian)

[8] Griadhi, I. K. W., Sirtha, I. N., and Swasthawa, I. M. 1993. "Subak in Law Perspective.” In Subak, Traditional Irrigation System in Bali, edited by Pitana, I. G. Denpasar: Upada Sastra Publisher. (in Indonesian)

[9] Sutawan. N. 2008. Organization and Management of Subak in Bali. Denpasar: Pustaka Bali Post. (in Indonesian)

[10] Purwita, I. B. P. 1993. "The Historical Study of Subak in Bali.” In Subak, Traditional Irrigation System in Bali, edited by Pitana, I. G. Denpasar: Upada Sastra Publisher. (in Indonesian)

[11] Norken, I. N., Suputra, I. K., and Arsana, I. G. N. K. 2010. "The History and Development of Sedahan as a Coordinator of Water Management for Subak in Bali."
Presented at International Commision on Irrigation and Drainage (ICID) Conference, October 10-16, 2010, Yogyakarta, Indonesia.

[12] Astawa, I. P. 2014. "Bali Development Data 2013." Government of Bali Province, Denpasar. Accesed Junuary 19, 2015. http://www.bappeda.baliprov.go.id/id/Bank-Data-Bapped a-2. (in Indonesian)

[13] Suputra, I. K. 2008. "Effectiveness of Water Resources Management for Subak Irrigation Water Needs in Denpasar.” Postgraduate thesis, University of Udayana, Denpasar. (in Indonesian)

[14] Pangdjaja, I. B. 1998. Guidance on Subak in Bali. Denpasar: Department of Culture of Province of Bali. (in Indonesian)

[15] Yuswari, M. N. 2010. "Farmer Community Participation (Subak) on Operation and Maintenance of Irrigation in Mambal Irrigation Area in Badung.” Postgraduate thesis, University of Udayana, Denpasar. (in Indonesian)

[16] Norken, I. N. 2016. "Subak Management: Problem and Solution.” Presented at National Seminar of Sustainable Subak Management at University of Ngurah Rai, Denpasar. (in Indonesian)

[17] Wahyudhi, I. M. A., Norken, I. N., and Suputra, I. K. 2015. "Participation of Stakeholders in Operation and Maintenance of Irrigation System in Unda Irrigation Area in Klungkung District.” J. Spektran 3 (2): 37-46. (in Indonesian).

[18] Norken, I. N., Suputra, I. K., and Arsana, I. G. N. K. 2012 "Subak Member Participation in Maintenance of Irrigation Networks: Case Study on Subak Pecelengan Pedukuhan in Mendoyo District, Jembrana Regency.” Civil Engineering Program, University of Udayana, Denpasar. (in indonesian).

[19] Pastika, M. M. 2012. "Regional Regulation (Perda) of Bali No. 9 of 2012 on Subak.” Provincial Legislature of Bali, Denpasar. Accessed February 1, 2015. http://whc.unesco.org/en/documents/134917. (in Indonesian)

[20] Norken, I. N., Suputra, I. K., and Arsana, I. G. N. K. 2015. "Water Resources Management of Subak Irrigation System in Bali." Applied Mechanics and Materials 776: 139-44.

[21] Gatra, S. 2015. "The Constitutional Court Cancel Entire Contents on Water Resources Law.” Accessed February 18, 2015. http://nasional.kompas.com/read/2015/02/18/230 10761/MK.Batalkan.Seluruh.Isi.di.UU. (in Indonesian)

[22] Norken, I. N. 1993 "Subak and Water Resources Development in Bali.” In Subak, Traditional Irrigation System in Bali, edited by Pitana, I. G. Denpasar: Upada Sastra Publisher.

[23] Sushila, J. 1987. Typical Characteristics of Subak 
Irrigation System in Bali. Sub-department of Irrigation, Public Works Department of Bali Province, Denpasar. (in Indonesian)

[24] Norken, I. N., Mudina, I. M., Geriya. I. W., Sushila, J., and Windia, I. W. 2007. Increased Effectiveness in Water Resources Management Based on Institutions Subak in Bali. Denpasar: Planning Agency of Bali Province. (in Indonesian) 